\title{
Timing of Nitrogen Fertilisation and the Effect of Poultry Manure on the Performance of Grapevines on Sandy Soil. I. Soil Analysis, Grape Yield and Vegetative Growth*
}

\author{
W.J. Conradie \\ ARC Infruitec-Nietvoorbij, Private Bag X5026, 7599 Stellenbosch, South Africa \\ Submitted for publication: October 2000 \\ Accepted for publication: June 2001 \\ Key words: Nitrogen, grapevine, application time, poultry manure, yield, vegetative growth, soil organic material
}

\begin{abstract}
A field trial with two Vitis vinifera L. cultivars, viz. Bukettraube (white) and Heroldrebe (red), grafted onto Ramsey, was carried out over a nine-year period on a sandy, duplex soil. The control $\left(N_{0}\right)$ received no $N$, while three other treatments each received $50 \mathrm{~kg} \mathrm{~N} / \mathrm{ha}$ in inorganic form. The $\mathrm{N}$ was applied either as three equal installments, split between budbreak, fruitset and post-harvest $\left(\mathrm{N}_{1}\right)$, or as a single application at budbreak $\left(\mathrm{N}_{2}\right)$, or as a single postharvest application $\left(N_{3}\right)$. A fifth treatment $\left(N_{4}\right)$ received $50 \mathrm{~kg} \mathrm{~N} /$ ha at budbreak in the form of poultry manure. A winter cover crop (rye) was sown after harvest, chemically controlled before budbreak with a herbicide and left as an organic mulch on the soil surface. This cover crop management system maintained the soil's organic material (SOM) at the original level for all inorganic treatments, while $\mathrm{N}_{4}$ increased SOM. On average, Bukettraube yielded $11.4 \mathrm{t} / \mathrm{ha}$, in comparison to only $6.0 \mathrm{t} / \mathrm{ha}$ for Heroldrebe. Yields of the four fertilised treatments $\left(\mathrm{N}_{1}, \mathrm{~N}_{2}, \mathrm{~N}_{3}\right.$ and $\mathrm{N}_{4}$ ) were comparable for each individual cultivar. Relative to $\mathrm{N}_{0}$, fertilisation increased yields by $24 \%$ and $48 \%$ for Bukettraube and Heroldrebe, respectively. In comparison to the control, all four fertilisation treatments increased shoot mass, with $N_{2}$ being significantly higher than $N_{1}, N_{3}$ and $N_{4}$. The fact that $N_{2}$ stimulated shoot growth, without a concomitant increase in yield, indicated that a single application of $\mathrm{N}$ at budbreak can cause excessive growth, even on low-potential soil. In the case of Bukettraube, grapes from the $\mathrm{N}_{2}$ treatment showed the highest incidence of bunch rot during some seasons. Under the cultivation practices followed in this trial, split applications of $\mathrm{N}$ (budbreak, fruitset, post-harvest) or a single application during the post-harvest period was compatible with the most desirable pattern of vine growth and fruit development. Application of poultry manure was not associated with any specific advantages or disadvantages. Soil analysis showed that the control vines were fairly well supplied with mineral $\mathbf{N}$ at budbreak, but under-supplied at the time of fruitset.
\end{abstract}

In the coastal regions of South Africa, grapevines are largely grown for the production of high-quality wines, either under dryland conditions, or with one to two irrigations annually. In order to obtain optimum wine quality, an acceptable balance between vegetative and reproductive growth is essential. Since injudicious $\mathrm{N}$ fertilisation can disturb this balance, applications should be timed to maximise levels of mineral $\mathrm{N}$ in the root zone during periods of peak $\mathrm{N}$ demand (Peacock, Christensen \& Hirschfeldt, 1991). The first major peak stretches from a few weeks prior to bloom up to véraison, and the second usually from harvest to leaffall (Conradie, 1980; Williams, 1991). In practice it is often difficult to synchronise fertiliser applications with these periods of peak demand, especially on sandy soils. If applied too early, spring rains may cause leaching before significant uptake can occur (Löhnertz, 1991; Peacock et al., 1991). On the other hand, large applications during the early part of the season may lead to dense canopies, resulting in bunch rot (Goldspink \& Gordon, 1991), while fruitfulness of buds may also be decreased in the following year (Hunter \& Visser, 1990; Smart et al., 1990). To overcome these problems, split applications of $\mathrm{N}$ can be considered (Brechbuhler \& Meyer 1988; Goldspink \& Gordon, 1991; Peacock et al., 1991). In practice this means that part of the annu- al $\mathrm{N}$ requirement is applied at fruitset. For irrigated vines the first irrigation should suffice to transport this $\mathrm{N}$ into the root zone. However, under South African climatic conditions the efficiency of $\mathrm{N}$ applications at fruitset is questionable in vineyards grown under dryland conditions.

Fertilisation during the second major period of root growth (post-harvest) maximises the amount of $\mathrm{N}$ in storage pools (Conradie, 1980; Conradie, 1986; Conradie, 1992; Peacock, Christensen \& Broadbent, 1989). Up to the time when root growth commences in early spring, aerial growth is heavily dependent on $\mathrm{N}$ mobilised from these pools. Positive responses to single applications of $\mathrm{N}$ during the post-harvest period have been reported (Conradie, 1986; Peacock et al., 1991; Christensen et al., 1994), but for some scion/rootstock combinations this approach appeared less effective (Goldspink \& Gordon, 1991; Treeby, Holzapfel \& Walker, 1995). Under South African climatic conditions it is of special importance to ascertain whether excess inorganic $\mathrm{N}$, applied during the post-harvest period on sandy soils, can be protected against leaching during the winter months. In Switzerland an actively growing cover crop has proved effective in this regard (Perret, Koblet \& Haab, 1989).

Application of $\mathrm{N}$ in the form of an organic source may also be 
a viable option for reducing leaching of $\mathrm{N}$ on sandy soils, due to the fact that $\mathrm{N}$ is released slowly from organic material (Kotze, Joubert \& Morkel, 1992). However, in a field trial with grapevines on a more clayey soil, significantly higher yields were obtained by inorganic fertilisation in comparison to an equivalent amount of organic N (Levy \& Chaler, 1976). In a study where poultry manure was applied at rates of 1-2 t/ha, yield was increased for Garganega, but decreased for Cabernet Sauvignon (Bavaresco et al., 1991). In South Africa the efficiency of an organic $\mathrm{N}$ source has not yet been compared with inorganic $\mathrm{N}$ sources for grapevines on sandy soils.

In a number of field trials no positive responses to $\mathrm{N}$ fertilisation, regarding yield and grape quality, were obtained where the level of $\mathrm{N}$ application exceeded $56 \mathrm{~kg} \mathrm{~N} / \mathrm{ha}$ (Conradie \& Saayman, 1989; Spayd et al., 1993; Christensen et al., 1994). Furthermore, due to differences between soils, cultivars, cultivation practices and climatic conditions, the magnitude of the response to $\mathrm{N}$ fertilisation differed between trials. Levels of soil organic matter (SOM) can have a particularly large effect on the amount of N required by grapevines (Chaler, 1978; Müller, 1986; Conradie \& Saayman, 1989; Fox, 1990). On soil containing $0.84 \%$ SOM grapevines utilised only $30 \%$ of the $\mathrm{N}$ which was applied during the previous season up to bloom in the following season. In contrast, $50 \%$ of the applied $\mathrm{N}$ was utilised over the same period for a soil containing $0.38 \%$ SOM (Conradie, 1986). The higher utilisation of fertiliser $\mathrm{N}$ in the latter case was ascribed to the lower level of inorganic $\mathrm{N}$, emanating from the mineralisation of SOM, resulting in less dilution and a higher utilisation of applied inorganic $\mathrm{N}$. Because the N-supplying capacity of a particular soil is thus directly linked to SOM, the effect of cropping systems on SOM has been investigated in several long-term trials, most of which have been reviewed by Champagnol (1980). In grapevine soils an equilibrium value for SOM could be ensured where 2-3 $t$ /ha of dry material was returned to the soil annually. From an environmental viewpoint it is important to maintain existing SOM levels, thereby making it unnecessary to increase applications of inorganic $\mathrm{N}$ progressively. The maintenance of SOM levels has not yet been investigated in South Africa in vineyards where a winter cover crop is sown.

In view of the above considerations a study was undertaken under typical South African cultivation conditions on a sandy soil with a low organic material content. The first objective was to quantify the effect of single applications of inorganic $\mathrm{N}$ (both at budbreak and post-harvest) relative to split applications (budbreak, fruitset and post-harvest). The second objective was to compare the utilisation efficiency of poultry manure, which is locally the most widely used source of organic $\mathrm{N}$, with that of judiciously applied inorganic $\mathrm{N}$.

\section{MATERIALS AND METHODS}

\section{Soil and experimental vineyard}

The investigation was carried out in the Stellenbosch district on a duplex soil (ochric planosol) classified as a Kroonstad form (Soil Classification Working Group, 1991). A leached albic E-horizon was present between $500 \mathrm{~mm}$ and $700 \mathrm{~mm}$. The E-horizon was underlaid by an argillic B-horizon. The soil was delve-ploughed to $600 \mathrm{~mm}$ before planting. Seven t/ha of agricultural lime and 300 $\mathrm{kg} /$ ha of superphosphate $(8.3 \% \mathrm{P})$ were incorporated during soil preparation. Grapevines were planted during 1979 at a spacing of $2.4 \mathrm{~m} \times 1.0 \mathrm{~m}$, and trained onto a Perold trellis, as described by Zeeman (1981). Two Vitis vinifera L. cultivars, Bukettraube (white) and Heroldrebe (red), both grafted onto Ramsey, were used.

\section{Experiment design and treatments}

A split-plot design was adopted. Individual plots $\left(108 \mathrm{~m}^{2}\right)$ were separated by at least one border row and by three border vines within rows. Twelve experimental vines per plot were used for measurements. Five treatments were applied (Table 1), commencing in 1981. Each was replicated three times. These consisted of a control (no $\mathrm{N}$ ), three inorganic $\mathrm{N}$ treatments, each receiving $50 \mathrm{~kg} \mathrm{~N} / \mathrm{ha} / \mathrm{yr}$ at different application times, and a fifth treatment which received $50 \mathrm{~kg} \mathrm{~N} / \mathrm{ha} / \mathrm{yr}$ in the form of poultry manure (PM). For the inorganic treatments the required amounts of limestone ammonium nitrate $(28 \% \mathrm{~N})$ were broadcasted over entire plots, while PM was concentrated in $800 \mathrm{~mm}$ wide bands on the vine rows. One tonne of the PM contained on average $31 \mathrm{~kg} \mathrm{~N}$, $18 \mathrm{~kg} \mathrm{P}$ and $17 \mathrm{~kg} \mathrm{~K}$. The $1600 \mathrm{~kg}$ of PM necessary to supply 50 $\mathrm{kg} \mathrm{N} / \mathrm{ha}$ therefore also supplied $29 \mathrm{~kg} \mathrm{P} / \mathrm{ha}$ and $27 \mathrm{~kg} \mathrm{~K} / \mathrm{ha}$. To compensate for the $\mathrm{K}$, equivalent amounts of potassium chloride were applied every third year to all other treatments. The P status of the soil was regarded as adequate and no compensation was therefore necessary. Agricultural lime ( $2 \mathrm{t} / \mathrm{ha}$ ) was applied every third year on the soil surface to maintain the $\mathrm{pH}(1 \mathrm{M} \mathrm{KCl})$ of the soil at approximately 5.5. Rye was sown annually as a winter cover crop, killed with a herbicide prior to budbreak and flattened to form an organic mulch on the soil surface. During summer the vines received two sprinkler irrigations of about $60 \mathrm{~mm}$ each. In order to schedule these irrigations, soil water content was determined gravimetrically once every two weeks during November, December and January. The first irrigation was normally required at fruitset (defined as two weeks after the end of bloom) and the second by middle January (approximately one month before harvest). Vines were spur pruned according to vigour and suckered a few weeks after budbreak. Apart from shoot positioning no further canopy management was done.

\section{Measurements}

Soil was sampled $300 \mathrm{~mm}$ from the vine rows during spring of the first year and thereafter every two to three years. Samples were analysed for $\mathrm{pH}(1: 2.5$ in $1 \mathrm{M} \mathrm{KCl}), \mathrm{P}$ (Bray No. 2 extract: 0.03 $\mathrm{M} \mathrm{NH}_{4} \mathrm{~F}$ in $0.01 \mathrm{M} \mathrm{HCl}$ ), $\mathrm{K}, \mathrm{Ca}$, and $\mathrm{Mg}$ (extracted with $1 \mathrm{M}$

\section{TABLE 1}

Source, quantity and timing of fertiliser nitrogen applied from $1981 / 82$ to $1989 / 90$.

\begin{tabular}{clccc}
\hline \multirow{2}{*}{ Treatment } & \multirow{2}{*}{$\begin{array}{c}\text { Source of } \\
\text { Nitrogen }\end{array}$} & \multicolumn{3}{c}{ Nitrogen applied (kg N/ha) } \\
\cline { 5 - 5 } & & 0 & 0 & 0 \\
\hline $\mathrm{N}_{0}$ & - & 17 & 16 & 17 \\
$\mathrm{~N}_{1}$ & Inorganic (2) & 50 & 0 & 0 \\
$\mathrm{~N}_{2}$ & Inorganic & 0 & 0 & 50 \\
$\mathrm{~N}_{3}$ & Inorganic & 50 & 0 & 0 \\
$\mathrm{~N}_{4}$ & Organic (3) & &
\end{tabular}

(1) Applied three weeks after actual date of budbreak

(2) Applied as limestone ammonium nitrate $(28 \% \mathrm{~N})$.

(3) Applied as poultry manure 
$\mathrm{NH}_{4} \mathrm{Cl}$ ), $\mathrm{CEC}$ (utilizing $1 \mathrm{M} \mathrm{NH}_{4} \mathrm{Cl}$ at the $\mathrm{pH}$ of the soil), organic C (The Non-Affiliated Soil Analysis Work Committee, 1990) and total $\mathrm{N}$ by means of a Kjeldahl digestion (Bremner \& Mulvaney 1982). During 1989/90 the soil was also sampled after harvest, at budbreak, at bloom and two weeks before harvest for determination of $\mathrm{NH}_{4}-\mathrm{N}$ and $\mathrm{NO}_{3}-\mathrm{N}$, by means of the distillation method described by Keeny \& Nelson (1982). In order to convert $\mathrm{NH}_{4}-\mathrm{N}$ and $\mathrm{NO}_{3}-\mathrm{N}$ concentrations to $\mathrm{kg} \mathrm{N} / \mathrm{ha}$, bulk densities were determined for the different soil horizons. The water holding capacity of the soil, down to a depth of $600 \mathrm{~mm}$, was determined on undisturbed soil cores employing standard pressure plate equipment. For this purpose profile pits were dug. Root distribution was also recorded in these pits. The amount of dry material, originating from the cover crop, was determined during 1989 on one plot for each of the five treatments. Rainfall was recorded at a weather station situated two kilometers from the experimental vineyard. Shoot mass and grape yield were measured for nine seasons (1981/82 to 1989/90). Both cultivars were harvested when the sugar concentration of Bukettraube averaged $21^{\circ} \mathrm{B}$.

\section{Statistical analysis}

Data was analysed statistically and Student's t LSD values were calculated at the $5 \%$ level of probability to facilitate comparison between treatment means.

\section{RESULTS AND DISCUSSION}

\section{Annual distribution of rainfall}

The long-term rainfall pattern (Table 2) showed that precipitation during April should normally be adequate to transport fertilisers applied during the post-harvest period into the root zone, while no undue leaching losses of $\mathrm{N}$ should occur. However, as $60 \%$ (418 $\mathrm{mm}$ ) of the annual precipitation occurred from May to August, leaching was expected during these months. Rainfall of $50 \mathrm{~mm}$, usually in the form of light showers, was normally expected from the fourth week in September to the end of October. This should have been sufficient to wash fertiliser, aimed at optimising N supply at the start of the first period of peak demand, into the soil without causing excessive leaching beyond the root zone. At the time of fruitset (normally first two weeks in December) rainfall was low. Fertilisation at this stage should therefore be accompanied by irrigation.

\section{Soil water status}

The clay content of the experimental soil was approximately $7 \%$, down to a depth of $600 \mathrm{~mm}$ (Table 3). The high coarse sand fraction contributed to a low plant available water-holding capacity of
$26 \mathrm{~mm}$ for the $0-600 \mathrm{~mm}$ layer. In spite of only $60 \mathrm{~mm}$ of rain during October and November (Table 2), the water content (data not shown) of the $200-400 \mathrm{~mm}$ and $400-600 \mathrm{~mm}$ layers was usually higher than $5 \%$ and $4 \%$, respectively, up to the end of November, thus exceeding wilting point (Table 3 ). This indicated that some of the water in the 750-1000 mm layer (argillic horizon) must have been utilised via capillary rise, despite few roots being present in this layer. Similar indications of upward movement of water into the root zone have been found previously (Saayman \& Kleynhans, 1978; Van Zyl \& Weber, 1981). Regardless of the seemingly low water-holding capacity, the grapevines never showed any visual symptoms of water stress before the end of November. Since soil water was adequately supplied up to the end of November, unimpeded uptake of mineral $\mathrm{N}$ should have proceeded at least up to fruitset. The first irrigation was normally applied at the beginning of December (fruitset), at which point soil water content was replenished to field capacity. After this irrigation, the soil dried out fairly rapidly and soil water was around wilting point during the two weeks preceding the second irrigation. Following the second irrigation, the soil again dried to wilting point (approximately 4\% soil water) down to rooting depth $(600 \mathrm{~mm})$, during the period preceding harvest (normally middle February). This is in agreement with the results of Van Zyl \& Weber (1981), who found that irrigations at fruitset

\section{TABLE 2}

Average rainfall, measured over a period of 18 years, two kilometers from the site where the fertilisation trial was carried out.

\begin{tabular}{lc}
\hline Month & Rainfall $(\mathbf{m m})$ \\
\hline January & 21.8 \\
February & 20.5 \\
March & 25.9 \\
April & 53.9 \\
May & 105.3 \\
June & 110.4 \\
July & 101.1 \\
August & 101.2 \\
September & 59.0 \\
October & 37.0 \\
November & 23.6 \\
December & 29.8 \\
\hline Total & 689.5 \\
\hline
\end{tabular}

\section{TABLE 3}

Physical analyses of Kroonstad soil used in fertilisation trial.

\begin{tabular}{|c|c|c|c|c|c|c|c|c|c|}
\hline \multirow[b]{2}{*}{$\begin{array}{l}\text { Soil depth } \\
\text { (mm) }\end{array}$} & \multicolumn{5}{|c|}{ Particle size distribution (\%) } & \multirow[b]{2}{*}{$\begin{array}{c}\text { Bulk } \\
\text { density } \\
\left(\mathrm{kg} / \mathrm{m}^{3}\right)\end{array}$} & \multicolumn{3}{|c|}{ Water holding capacity } \\
\hline & $\underset{(<0.002 \mathrm{~mm})}{\text { Clay }}$ & $\begin{array}{c}\text { Silt } \\
(0.02- \\
0.002 \mathrm{~mm})\end{array}$ & $\begin{array}{c}\text { Fine sand } \\
(0.2-0.02 \mathrm{~mm})\end{array}$ & $\begin{array}{l}\text { Medium sand } \\
(0.5-0.2 \mathrm{~mm})\end{array}$ & $\begin{array}{c}\text { Coarse sand } \\
(2.0-0.5 \mathrm{~mm})\end{array}$ & & $\begin{array}{l}\text { Water content } \\
\text { at field } \\
\text { capacity }(1) \\
(\text { Vol. \%) }\end{array}$ & $\begin{array}{l}\text { Water content } \\
\text { at wilting } \\
\text { point }(2) \\
(\text { Vol. } \%)\end{array}$ & $\begin{array}{c}\text { Plant available } \\
\text { water } \\
(\mathbf{m m})\end{array}$ \\
\hline $0-200$ & 6.9 & 4.5 & 28.0 & 22.0 & 37.9 & 1716 & 9.19 & 5.16 & 8.1 \\
\hline $200-400$ & 6.6 & 4.2 & 26.2 & 21.4 & 41.0 & 1723 & 9.82 & 4.77 & 10.1 \\
\hline $400-600$ & 6.7 & 4.2 & 23.1 & 22.8 & 43.3 & 1698 & 7.39 & 3.36 & 8.1 \\
\hline
\end{tabular}

(1) Field capacity defined as the amount of water retained at a pressure of $0.005 \mathrm{MPa}$.

(2) Wilting point defined as the amount of water retained at a pressure of 1.5 MPa. 
and véraison were insufficient to maintain soil water above wilting point. Mineralisation of SOM and uptake of $\mathrm{N}$ will be impeded under dry soil conditions (Haynes, 1986).

\section{Chemical analyses of soil}

Before the trial commenced the $\mathrm{pH}$ of the soil (Table 4) was in the optimal range of 5.5 to 6.0 (Conradie, 1983), while $\mathrm{P}$ and $\mathrm{K}$ were also adequate for cultivation of grapevines (Conradie \& Saayman, 1989). The dystrophic nature of the soil was confirmed by low $\mathrm{Ca}$ and $\mathrm{Mg}$ contents and a low cation exchange capacity. The average $C$ content of the $0-600 \mathrm{~mm}$ soil layer was $0.27 \%$, which was equivalent to $0.46 \%$ SOM. In all cases the SOM content of the 0-200 mm layer was considerably higher than that of the deeper soil layers $(200-600 \mathrm{~mm})$. This is in agreement with results obtained elsewhere (Champagnol, 1980).

Soil sampling at the beginning (Table 4) and end of the experiment (Table 5) was done at slightly different depths and values cannot be compared directly. In the case of $\mathrm{P}$, however, it was clear that a reduction in the nutritional status of the $0-300 \mathrm{~mm}$ soil layer occurred for the control $\left(\mathrm{N}_{0}\right)$ and the three inorganic $\mathrm{N}$ treatments $\left(\mathrm{N}_{1}, \mathrm{~N}_{2}\right.$ and $\left.\mathrm{N}_{3}\right)$. In spite of this reduction the $\mathrm{P}$ level was still higher than $25 \mathrm{mg} / \mathrm{kg}$, the value regarded as adequate for soil of this texture (Saayman, 1981). Organic fertilisation increased the $P$ level down to a depth of $600 \mathrm{~mm}$, indicating that some of the P must have moved to the subsoil. Similar indications were found on a more clayey soil (Conradie \& Saayman, 1989).

At the end of the investigation period the $\mathrm{K}$ content (Table 5) of topsoil $(0-150 \mathrm{~mm})$ appeared to have been reduced for the control and inorganic treatments in comparison to the situation at the start of the experiment. The $\mathrm{K}$ content of topsoil $(0-150 \mathrm{~mm})$ from the PM treatment $\left(\mathrm{N}_{4}\right)$ increased during the investigation. However, in view of the fact that soil samples were taken in the zone where the PM was banded, $\mathrm{K}$ content may have been lower towards the middle of the row. Furthermore, sampling was done during spring, shortly after application of PM. The fact that the subsoil (300-600 mm) contained comparable amounts of $\mathrm{K}$ for all treatments, indicated that a major share of the $\mathrm{K}$ present in the topsoil of $\mathrm{N}_{4}$, after application of PM, was either utilised by the grapevines during the growing season or was leached from the root zone during winter. However, from budbreak to harvest $\mathrm{K}$ supply was probably higher for $\mathrm{N}_{4}$ than for the other treatments.
At the end of the nine-year investigation period SOM in the 0$600 \mathrm{~mm}$ layer of $\mathrm{N}_{0}$ (Table 5) was comparable to the situation at the start (Table 4). For the PM treatment SOM increased $43.4 \%$ over the control. As in the case of $\mathrm{P}$ and $\mathrm{K}$, this increase may have been confined to the band where the PM was applied. The three inorganic treatments $\left(\mathrm{N}_{1}, \mathrm{~N}_{2}\right.$ and $\left.\mathrm{N}_{3}\right)$ were intermediate to $\mathrm{N}_{0}$ and $\mathrm{N}_{4}$, with about $20 \%$ more SOM than $\mathrm{N}_{0}$. In comparison to the control, the cover crop grew more vigorously on the fertilised treatments, resulting in an additional one tonne of dry material/ha. This may have led to higher SOM levels (Liang \& Mackenzie, 1992). A comparable increase of $18 \%$ was found after six years of continuous corn cultivation, where the crop residues were returned to the soil (Liang \& Mackenzie, 1992).

In general, an equilibrium value for SOM can be ensured in vineyard soils under long-term cultivation if 2-3 $\mathrm{t} /$ ha of dry material is returned to the soil annually (Champagnol, 1980). Since the soil used in the current investigation had probably been under grapevines for at least 100 years, an equilibrium value for SOM should therefore have been attained. The values in Table 5 indicated that this equilibrium value was certainly maintained over the nine-year trial period, while a trend towards increased SOM levels could not be discounted for the inorganically fertilised treatments. Total $\mathrm{N}$ levels did not differ significantly (Table 5), but tended to be slightly higher in soil from the PM treatment.

\section{Seasonal variations in mineral $\mathbf{N}$ contents of the soil}

The amount of $\mathrm{NH}_{4}-\mathrm{N}$ in soils from the different treatments showed only small variations, never exceeding $20 \mathrm{~kg} \mathrm{~N} / \mathrm{ha}$ in the 0-600 mm layer (data not shown). The $\mathrm{NO}_{3}-\mathrm{N}$ level of subsoil $(300-600 \mathrm{~mm})$ also showed little variation and amounted to approximately $20 \mathrm{~kg} \mathrm{~N} /$ ha throughout the season. Consequently, only values for topsoil $(0-300 \mathrm{~mm})$ are shown in Table 6 . Fertilisation at budbreak did not increase $\mathrm{NO}_{3}-\mathrm{N}$ for $\mathrm{N}_{1}$, while $\mathrm{N}_{2}$ increased less than was expected. This confirmed that the mineral-N level of soil does not always correlate with the quantity of applied fertiliser (Neyroud \& Parisod, 1983). In contrast, application of PM increased soil $\mathrm{NO}_{3}-\mathrm{N}$. At fruitset $\mathrm{NO}_{3}-\mathrm{N}$ was lowest for the control treatment. In view of the fact that the subsoil (300$600 \mathrm{~mm}$ ) contained about $20 \mathrm{~kg} \mathrm{~N} /$ ha throughout the year, mineral- $\mathrm{N}$ in the root zone at the time of fruitset must have amounted to approximately $65 \mathrm{~kg} \mathrm{~N} / \mathrm{ha}$ for all inorganically fertilised treat-

\section{TABLE 4}

Chemical analyses of Kroonstad soil before the trial commenced.

\begin{tabular}{|c|c|c|c|c|c|c|c|c|}
\hline $\begin{array}{l}\text { Soil depth } \\
\quad(\mathrm{mm})\end{array}$ & pH ${ }^{(1)}$ & $\begin{array}{c}\mathbf{P}^{(2)} \\
(\mathbf{m g} / \mathbf{k g})\end{array}$ & $\begin{array}{c}\mathrm{K}^{(3)} \\
(\mathrm{mg} / \mathrm{kg})\end{array}$ & $\begin{array}{c}\mathrm{Ca}(3) \\
(\mathbf{m g} / \mathbf{k g})\end{array}$ & $\begin{array}{c}\mathrm{Mg}(3) \\
(\mathbf{m g} / \mathbf{k g})\end{array}$ & $\begin{array}{l}C(4) \\
(\%)\end{array}$ & $\begin{array}{l}\text { Soil Organic (5) } \\
\text { Material (\%) }\end{array}$ & $\begin{array}{c}\mathrm{CEC}^{(6)} \\
(\mathrm{meq} / \mathbf{1 0 0} \mathrm{g})\end{array}$ \\
\hline $0-200$ & 6.0 & 53 & 62 & 270 & 96 & 0.48 & 0.82 & 3.01 \\
\hline $200-400$ & 5.7 & 49 & 53 & 296 & 72 & 0.17 & 0.29 & 2.31 \\
\hline $400-600$ & 5.5 & 24 & 47 & 232 & 58 & 0.16 & 0.27 & 1.86 \\
\hline Mean & 5.7 & 42 & 542 & 66 & 75 & 0.27 & 0.46 & 2.39 \\
\hline
\end{tabular}

(1) Measured in $1 \mathrm{M} \mathrm{KCI} \mathrm{(1:2.5).}$

(2) Bray No. 2 extract.

(3) Extracted with $1 \mathrm{M} \mathrm{NH}_{4} \mathrm{Cl}$.

(4) Walkley-Black method.

(5) Soil organic material $=1.717 \times \%$.

(6) Cation exchange capacity, as determined with the $\mathrm{NH}_{4} \mathrm{Cl}$ method at $\mathrm{pH}$ of the soil. 
TABLE 5

Chemical analyses of soil from the different treatments after nine years of differential fertilisation.

\begin{tabular}{|c|c|c|c|c|c|c|c|c|c|c|}
\hline \multirow{3}{*}{ Treatment ${ }^{(1)}$} & \multicolumn{3}{|c|}{$P(\mathbf{m g} / \mathbf{k g})$} & \multicolumn{3}{|c|}{ K (mg/kg) } & \multirow{3}{*}{$\begin{array}{l}C^{(3)} \\
(\%)\end{array}$} & \multirow{3}{*}{$\begin{array}{c}\text { Soil organic } \\
\text { material (3) } \\
(\%)\end{array}$} & \multirow{3}{*}{$\begin{array}{c}N^{(3)} \\
(\mathrm{mg} / \mathbf{k g})\end{array}$} & \multirow{3}{*}{$\mathbf{C} / \mathbf{N}$} \\
\hline & \multicolumn{3}{|c|}{ Soil depth (mm) } & \multicolumn{3}{|c|}{ Soil depth (mm) } & & & & \\
\hline & $0-150$ & $150-300$ & $300-600$ & $0-150$ & $150-300$ & $300-600$ & & & & \\
\hline $\mathrm{N}_{0}$-Control & $43 \mathrm{a}^{(2)}$ & $34 \mathrm{a}$ & $32 \mathrm{ab}$ & $47 \mathrm{a}$ & $47 \mathrm{ab}$ & $44 \mathrm{a}$ & $0.305 \mathrm{a}$ & $0.52 \mathrm{a}$ & $224 \mathrm{a}$ & 13.6 \\
\hline $\mathrm{N}_{1}$-Split application & $43 \mathrm{a}$ & $27 \mathrm{a}$ & $25 \mathrm{a}$ & $47 \mathrm{a}$ & $31 \mathrm{a}$ & $34 \mathrm{a}$ & $0.375 \mathrm{ab}$ & $0.64 \mathrm{ab}$ & $234 \mathrm{a}$ & 16.0 \\
\hline $\begin{array}{l}\mathrm{N}_{2} \text {-Budburst } \\
\text { application }\end{array}$ & $43 \mathrm{a}$ & $46 \mathrm{ab}$ & $30 \mathrm{ab}$ & $45 \mathrm{a}$ & $54 \mathrm{~b}$ & $46 \mathrm{a}$ & $0.355 \mathrm{ab}$ & $0.61 \mathrm{ab}$ & $226 \mathrm{a}$ & 15.7 \\
\hline $\begin{array}{l}\mathrm{N}_{3} \text {-Post-harvest } \\
\text { application }\end{array}$ & $46 \mathrm{a}$ & $36 \mathrm{a}$ & $30 \mathrm{ab}$ & $58 \mathrm{a}$ & $35 \mathrm{a}$ & $42 \mathrm{a}$ & $0.375 \mathrm{ab}$ & $0.64 \mathrm{ab}$ & $234 \mathrm{a}$ & 16.0 \\
\hline $\mathrm{N}_{4}$-Poutlry manure & $59 \mathrm{~b}$ & $56 \mathrm{~b}$ & $42 b$ & $95 \mathrm{~b}$ & $56 \mathrm{~b}$ & $43 \mathrm{a}$ & $0.437 \mathrm{~b}$ & $0.75 \mathrm{~b}$ & $310 \mathrm{a}$ & 14.1 \\
\hline
\end{tabular}

(1) See Table 1 for details of treatments.

(2) Values within columns followed by the same letter do not differ significantly $(\rho \leq 0.05)$.

(3) Values are for $0-600 \mathrm{~mm}$ soil depth.

ments. The control contained approximately $50 \mathrm{~kg} \mathrm{~N} / \mathrm{ha}$. If a value of $60-70 \mathrm{~kg} \mathrm{~N} / \mathrm{ha}$ is regarded as sufficient (Löhnertz, 1991), vines from the $\mathrm{N}_{0}$ treatment must have suffered $\mathrm{N}$ deficiency before fruitset. Between the second (fruitset) and the third (two weeks before harvest) sampling dates, $\mathrm{NO}_{3}-\mathrm{N}$ was reduced by 15 $\mathrm{kg} / \mathrm{ha}$ for the control. For grapevines yielding around 10-12 t/ha, this amount may well be insufficient to supply the demand (approximately $20 \mathrm{~kg} \mathrm{~N}$ ) over the relevant period (Conradie, 1980). Low soil water contents, occurring periodically during December, January and February probably lead to low mineralisation of SOM and low uptake of N (Haynes, 1986), thus contributing to the under-supply of N. During the same period (fruitset to two weeks before harvest) the $\mathrm{NO}_{3}-\mathrm{N}$ level in fertilised soils was reduced by values ranging from $23 \mathrm{~kg} / \mathrm{ha}$ to $34 \mathrm{~kg} / \mathrm{ha}$, indicating satisfactory $\mathrm{N}$ supply. As in the case of SOM, the fact that PM was banded and that soil was sampled within this band may have inflated the value for $\mathrm{N}_{4}$. A slightly lower $\mathrm{N}$-supplying capacity for $\mathrm{N}_{4}$, in comparison to the inorganically fertilised treatments, was confirmed by leaf analysis (Conradie, 2001). Higher soil $\mathrm{NO}_{3}-\mathrm{N}$ concentrations were obtained for all treatments in the post-harvest period. This was probably due to increased rates of mineralisation, following rain in April (Table 2). However, the effect of post-harvest fertilisation could still be detected for $\mathrm{N}_{1}$ and $\mathrm{N}_{3}$. For the latter treatment the increase of $86 \mathrm{~kg} / \mathrm{ha}$ was actually more than the amount of $\mathrm{N}(50 \mathrm{~kg} / \mathrm{ha})$ applied. At the postharvest stage mineral- $\mathrm{N}$ concentration was comparable for $\mathrm{N}_{0}$ and $\mathrm{N}_{4}$, indicating that PM had little, if any, slow-release capabilities over this period.

\section{Grape yield and shoot mass}

During the first two seasons of the investigation (1981/82 and $1982 / 83$ ) no differences in yield or shoot growth were detected (data not shown). From the third season onwards fairly consistent trends emerged and only mean values for the last seven seasons are shown in Table 7. For Bukettraube, shoot mass was lowest for $\mathrm{N}_{0}$ and highest for $\mathrm{N}_{2}$, while no differences occurred between $\mathrm{N}_{1}$, $\mathrm{N}_{3}$ and $\mathrm{N}_{4}$. The fact that a single application of $\mathrm{N}$ at budbreak $\left(\mathrm{N}_{2}\right)$ can stimulate vegetative growth, is consistent with other results (Goldspink \& Gordon, 1991). Under the conditions of this trial, leaching of $\mathrm{N}$ due to spring rain (Peacock et al., 1991) could not

\section{TABLE 6}

Seasonal variations in $\mathrm{NO}_{3}-\mathrm{N}$ content of the $0-300 \mathrm{~mm}$ soil layer measured during 1989/99 for the different treatments ( $\mathrm{kg} \mathrm{N} / \mathrm{ha})$.

\begin{tabular}{lllcc}
\hline \multicolumn{1}{c}{ Treatment (1) } & \multicolumn{4}{c}{ Sampling time } \\
\cline { 2 - 5 } & $\begin{array}{c}\text { Five weeks } \\
\text { after bud- } \\
\text { break (2) }\end{array}$ & Fruitset (3) & $\begin{array}{c}\text { Two weeks } \\
\text { before } \\
\text { harvest }\end{array}$ & $\begin{array}{c}\text { After } \\
\text { harvest (4) }\end{array}$ \\
\hline $\mathrm{N}_{0}$-Control & $55 \mathrm{a}(5)$ & $31 \mathrm{a}$ & $16 \mathrm{a}$ & $54 \mathrm{a}$ \\
$\mathrm{N}_{1}$-Split application & $57 \mathrm{a}$ & $44 \mathrm{ab}$ & $21 \mathrm{a}$ & $71 \mathrm{a}$ \\
$\mathrm{N}_{2}$-Budbreak application & $75 \mathrm{a}$ & $46 \mathrm{ab}$ & $17 \mathrm{a}$ & $59 \mathrm{a}$ \\
$\mathrm{N}_{3}$-Post-harvest application & $69 \mathrm{a}$ & $47 \mathrm{ab}$ & $19 \mathrm{a}$ & $140 \mathrm{~b}$ \\
$\mathrm{~N}_{4}$-Poultry manure & $104 \mathrm{~b}$ & $57 \mathrm{~b}$ & $23 \mathrm{a}$ & $41 \mathrm{a}$ \\
\hline
\end{tabular}

(1) See Table 1 for details of treatments.

(2) Sampled after budbreak fertilisation.

(3) Sampled before fruitset fertilisation.

(4) Sampled after post-harvest fertilisation.

(5) Values within columns followed by the same letter do not differ significantly $(\rho \leq 0.05)$.

have been a major factor and $\mathrm{N}$ applied at budbreak was apparently freely available. Heroldrebe grew less vigorously than Bukettraube, with shoot mass being about 50\% lower. As in the case of Bukettraube, shoot mass was lowest for $\mathrm{N}_{0}$ and highest for $\mathrm{N}_{2}$, with intermediate values for $\mathrm{N}_{3}$ and $\mathrm{N}_{4}$. In contrast to Bukettraube, shoot mass was relatively low for split applications $\left(\mathrm{N}_{1}\right)$, suggesting that $\mathrm{N}$ applications at fruitset do not stimulate shoot growth for low-vigour cultivars. Similar indications of a less dense canopy where $\mathrm{N}$ is applied between fruitset and véraison, in comparison to applications at budbreak, have been reported previously (Goldspink \& Gordon, 1991).

For Bukettraube the control $\left(\mathrm{N}_{0}\right)$ yielded less than $\mathrm{N}_{3}$ and $\mathrm{N}_{4}$. Yields of $N_{1}$ and $N_{2}$ did not differ significantly $(\rho \leq 0.05)$ from that of the control, but yields of the four fertilised treatments could be regarded as identical for all practical purposes. Mean yield of the fertilised treatments $(2.74 \mathrm{~kg} / \mathrm{vine})$, equivalent to 11.4 $\mathrm{t} / \mathrm{ha}$, was $24 \%$ higher than that of the control (9.2 $\mathrm{t} / \mathrm{ha})$. Yield of Heroldrebe was about $50 \%$ lower than that of Bukettraube, but 


\section{TABLE 7}

Effect of different application times and sources of $\mathrm{N}$ on grape yield and shoot mass of Bukettraube and Heroldrebe (Means for 1983/84 to $1989 / 90$ ).

\begin{tabular}{|c|c|c|c|c|c|}
\hline \multirow[b]{2}{*}{ Treatment ${ }^{(1)}$} & \multicolumn{3}{|c|}{ Bukettraube } & \multicolumn{2}{|c|}{ Heroldrebe } \\
\hline & $\begin{array}{c}\text { Shoot } \\
\text { mass } \\
\text { (kg/vine) }\end{array}$ & $\begin{array}{c}\text { Yield } \\
\text { (kg/vine) }\end{array}$ & $\begin{array}{c}\text { Bunch } \\
\text { rot }(2) \\
(\%)\end{array}$ & $\begin{array}{c}\text { Shoot } \\
\text { mass } \\
\text { (kg/vine) }\end{array}$ & $\begin{array}{c}\text { Yield } \\
\text { (kg/vine) }\end{array}$ \\
\hline$\overline{\mathrm{N}_{0} \text {-Control }}$ & $0.44 \mathrm{a}^{(3)}$ & $2.20 \mathrm{a}$ & $5.3 \mathrm{a}$ & $0.21 \mathrm{a}$ & $0.97 \mathrm{a}$ \\
\hline $\mathrm{N}_{1}$-Split application & $0.60 \mathrm{~b}$ & $2.69 \mathrm{ab}$ & $12.1 \mathrm{ab}$ & $0.25 \mathrm{a}$ & $1.33 \mathrm{ab}$ \\
\hline $\mathrm{N}_{2}$-Budbreak application & $0.75 \mathrm{c}$ & $2.72 \mathrm{ab}$ & $24.0 \mathrm{~b}$ & $0.39 \mathrm{~b}$ & $1.52 \mathrm{~b}$ \\
\hline $\mathrm{N}_{3}$-Post-harvest application & $0.62 \mathrm{bc}$ & $2.78 \mathrm{~b}$ & $8.1 \mathrm{a}$ & $0.30 \mathrm{c}$ & $1.35 \mathrm{~b}$ \\
\hline $\mathrm{N}_{4}$-Poultry manure & $0.55 a b$ & $2.76 \mathrm{~b}$ & $6.3 \mathrm{a}$ & $0.32 \mathrm{c}$ & $1.57 \mathrm{~b}$ \\
\hline
\end{tabular}

(1) See Table 1 for details.

(2) Percentage of berries showing signs of botrytis infection, values for 1984/85 and 1988/89 only.

(3) Values within columns followed by the same letter do not differ significantly $(\rho \leq 0.05)$.

showed the same trends for fertilised treatments. Mean yield $(1.44 \mathrm{~kg} / \mathrm{vine})$ of the four fertilised treatments, equivalent to 6.01 $\mathrm{t} / \mathrm{ha}$, was $48 \%$ higher than that of the control (4.04 t/ha). The $\mathrm{N}$ fertilisation effect was thus more pronounced than for Bukettraube. Yields were comparable to the South African average for white (8-10 t/ha) and red (5-6 t/ha) cultivars, grown for the production of high-quality wines in the coastal regions (Anonymous, 2000).

The ratio between yield and shoot mass (Y:SM), for Bukettraube amounted to 5.0 for $\mathrm{N}_{0}$ and $\mathrm{N}_{4}$. This agrees with the value of 4.9, obtained for adequately fertilised Chenin blanc/Ramsey in the Stellenbosch district (Zeeman \& Archer, 1981), indicating that the vines from both treatments maintained a balanced growth pattern, despite a $24 \%$ difference in yield. A slightly lower Y:SM ratio (4.5) for $\mathrm{N}_{1}$ and $\mathrm{N}_{3}$ suggested a marginal increase in vigour, while a much lower value (3.6) for Y:SM confirmed excessive vigour in the case of $\mathrm{N}_{2}$. Even though positive yield responses due to fertilisation are always accompanied with increased shoot growth (Champagnol, 1978), it is accepted that increased vegetative growth does not necessarily induce higher yields. Increased vegetative growth may even reduce yields due to excessive shading of fruiting zones, resulting in decreased fruitfulness of buds in the following year (Champagnol, 1978; Hunter \& Visser, 1990; Smart et al., 1990). The fact that $\mathrm{N}_{2}$ did not increase the yield of Bukettraube relative to $\mathrm{N}_{0}$ was probably attributable to these factors. Since Heroldrebe did not grow vigorously, a positive yield response may have been expected for $\mathrm{N}_{2}$. The fact that this was not the case accords with the belief that grapevines, grown under specific conditions, need a distinct minimum $\mathrm{N}$ supply and that once this requirement has been satisfied further application of $\mathrm{N}$ will not increase the yield (Löhnertz, 1991; Spayd et al., 1993). In the current experiment all four fertilisation treatments were probably capable of ensuring that this minimum level of $\mathrm{N}$ availability was met. As in the case of Bukettraube, the lowest Y:SM ratio (3.9) was found for $\mathrm{N}_{2}$, while values ranged from 4.6 to 5.3 for the other treatments.
Bunch rot occurred in Bukettraube during 1984/85 and 1988/89 (Table 7). Grapes from $\mathrm{N}_{2}$ showed the highest rate of infection, in comparison to $\mathrm{N}_{0}, \mathrm{~N}_{3}$ and $\mathrm{N}_{4}$. This was due to denser canopies and to climatic conditions conducive to Botrytis cinerea infection. Comparable results for $\mathrm{N}$ applications at budbreak have been reported previously (Goldspink \& Gordon, 1991). Bunch rot was never observed in Heroldrebe.

The fact that a single post-harvest application of nitrogen $\left(\mathrm{N}_{3}\right)$ was as effective as the other fertilisation treatments on the trial soil, where leaching of inorganic $\mathrm{N}$ was expected during winter, was surprising. The winter cover crop (rye), sown at the same time as the post-harvest $\mathrm{N}$ application, could have contributed to this positive response. The active growth stage of the cover crop coincided with the period of heavy rainfall, possibly resulting in the cover crop absorbing mineral $\mathrm{N}$ not utilised by the grapevines. In this way inorganic $\mathrm{N}$ can be converted to the organic form to become available again through the process of mineralisation after the cover crop is killed with a herbicide. This is in agreement with results obtained in Switzerland (Perret, Koblet \& Haab, 1989). Under clean cultivation, where inorganic $\mathrm{N}$ is not protected against leaching during the winter months, post-harvest fertilisation may be less effective, especially on sandy soils. In such cases split-applications of $\mathrm{N}$ (budbreak, fruitset and post-harvest) may be preferable.

In comparison to the other fertilised treatments, PM tended to increase the yield of Heroldrebe from 1987 to 1989 (Van Huyssteen \& Conradie, 1990). Even though no significant effect could be detected for the entire investigation period (Table 7), yield still tended to be highest for $\mathrm{N}_{4}$, in spite of moderate shoot growth. Despite the $\mathrm{K}$ content of soils from $\mathrm{N}_{1}, \mathrm{~N}_{2}$ and $\mathrm{N}_{3}$ being adequate at the end of the trial (Table 5), maintenance applications of $\mathrm{K}$ were carried out every three years only, and leaf analysis suggested that temporary $\mathrm{K}$ deficiencies could not be excluded for the inorganic treatments (Conradie, 2001). The possibility of a positive response to PM during specific seasons must therefore be ascribed to the $\mathrm{K}$ in the PM, and not to slow release of $\mathrm{N}$. In this trial organic $\mathrm{N}$ held no specific advantages or disadvantages in comparison to inorganic $\mathrm{N}$. It has been suggested that PM will release only $50 \%$ of its total $\mathrm{N}$ over the first year (Alberti \& Raath, 1994). A build-up of organic $\mathrm{N}$ is expected in the soil after multiple yearly applications. However, over the long term the amount of $\mathrm{N}$ applied as PM may have to be increased by $50 \%$ in order to supply the same amount of $\mathrm{N}$ as inorganic fertilisers (Kotze et al., 1992).

\section{CONCLUSIONS}

In the current investigation a single post-harvest application of $\mathrm{N}$, and split $\mathrm{N}$ applications (budbreak, fruitset and post-harvest) gave similar results and ensured balanced growth. However, these results were obtained in a vineyard where a winter cover crop was grown. Post-harvest fertilisation may be less effective under clean cultivation practices and unabsorbed $\mathrm{N}$ may be lost during winter through leaching. The cover crop management system also ensured that existing levels of soil organic material were maintained and possibly increased.

A single application of $\mathrm{N}$ at budbreak stimulated vegetative growth, but no concomitant increase in yield was found. Therefore, it is clear that excessive applications of $\mathrm{N}$ at budbreak 
should normally be avoided, even on low-potential soils, unless intensive canopy management practices are followed. However, in low-vigour vineyards fairly heavy applications of $\mathrm{N}$ at budbreak or soon after should be beneficial.

Application of poultry manure held no specific advantages or disadvantages, in comparison to inorganic $\mathrm{N}$ sources, but the $\mathrm{K}$ content of poultry manure may be an added benefit on sandy soils. Economic considerations should dictate the choice between organic and inorganic fertilisers.

Results were obtained for low-yielding cultivars on sandy soil with a relatively low potential. Most of the principles should also be applicable to high-yielding cultivars on fertile soil. However, in order to increase the efficiency of $\mathrm{N}$ applications, more intensive irrigation will be required under more arid conditions.

\section{LITERATURE CITED}

Alberti, I. \& Raath, P.J., 1994. The nitrogen releasing capacity of processed poultry manure compared with that of different organic materials. Decid. Fruit. Grow. 44, 376-379.

Anonymous, 2000. S.A. Industry Statistics No. 24. SAWIS, P.O. Box 238, 7620 Paarl, South Africa.

Bavaresco, L., Fraschini, P., Ubigli, M., Di Stefano, R., Versini, G. \& Nicolini, G., 1991. Sperimentazione pluriennale di concimazio ne organica del vigneto con pollina granulare. Effeti sull'uva e sul vino. Vignevini 4, 59-71.

Brechbuhler, C. \& Meyer, E., 1988. Ergebnisse eines Düngungsversuchs mit geteilten Stickstoffgaben. Mitt. Klosterneuburg 38, 170-172.

Bremner, J.M. \& Mulvaney, C.S., 1982. Total nitrogen. In: Page, A.L., Miller, R.H. \& Keeney, D.R. (eds). Methods of soil analysis, Part 2. American Society of Agronomy, Madison. pp. 595-624.

Chaler, G., 1978. Utilisation des matiéres organiques dans le vignoble francais. Vignes Vins 270, 33-43.

Champagnol, F., 1978. Fertilisation optimale de la vigne. Progrés agric. vitic. 95, 423-440.

Champagnol, F., 1980. La matiére organique des sols de vigne du Midi de la France. Progrés agric. vitic. 97, 161-173.

Christensen, L.P., Bianchi, M.L., Peacock, W.L. \& Hirschfelt, D.J., 1994. Effect of nitrogen fertiliser timing and rate on inorganic nitrogen status, fruit composition and yield of grapevines. Am. J. Enol. Vitic. 45, 377-387.

Conradie, W.J., 1980. Seasonal uptake of nutrients by Chenin blanc in sand culture. 1. Nitrogen. S. Afr. J. Enol. Vitic. 1, 59-65.

Conradie, W.J., 1983. Liming and choice of rootstocks as cultural techniques for vines in acid soils. S. Afr. J. Enol Vitic. 4, 39-44.

Conradie, W.J., 1986. Utilisation of nitrogen by the grapevine as affected by time of application and soil type. S. Afr. J. Enol. Vitic. 7, 76-82.

Conradie, W.J., 1992. Partitioning of nitrogen in grapevines during autumn and the utilisation of nitrogen reserves during the following growing season. S. Afr. J. Enol. Vitic. 13, 45-51.

Conradie, W.J., 2001. Timing of nitrogen fertilisation and the effect of poultry manure on the performance of grapevines on sandy soil. II. Leaf analysis, juice analysis and wine quality. S. Afr. J. Enol. Vitic. 22, 60-68.

Conradie, W.J. \& Saayman, D., 1989. Effects of long-term nitrogen, phosphorus and potassium fertilisation on Chenin blanc vines. I. Nutrient demand and vine performance. Am. J. Enol. Vitic. 40, 85-90.

Fox, R., 1990. Nitrogen supply and soil cultivation. Dtsch. Weinbau 45, 932-935.

Goldspink, B. \& Gordon, C., 1991. Response of Vitis vinifera cv. Sauvignon blanc grapevines to timed applications of nitrogen fertilisers. In: Rantz, J.M. (ed). Proc. Int. Symp. on Nitrogen in Grapes and Wine, 18-19 June 1991, Seattle, Washington, USA. pp. 255-258.

Haynes, R.J., 1986. Mineral nitrogen in the plant-soil system. Academic Press Inc., Orlando, Florida.

Hunter, J.J. \& Visser, J.H., 1990. The effect of partial defoliation on some growth characteristics of Vitis vinifera L. cv. Cabernet Sauvignon. II. Reproductive growth. S. Afr. J. Enol. Vitic. 11, 26-32.

Keeney, D.R. \& Nelson. D.W., 1982. Nitrogen - Inorganic forms. In: Page, A.L. Miller, R.H. \& Keeney, D.R. (eds). Methods of Soil Analysis, Part 2. American Society of Agronomy, Madison. pp. 643-698.

Kotze, W.A.G., Joubert, Marlise \& Morkel, Suret, 1992. Poultry manure as fertiliser for deciduous fruit production. Decid. Fruit. Grow. 42, 250-255.

Levy, J.F. \& Chaler, G., 1976. Étude comparative de l'action de l'azote organique et de l'azote minéral sur vigne réactive a l'azote. Vignes Vins 246, 37-41.

Liang, B.C. \& Mackenzie, A.F., 1992. Changes in soil organic carbon and nitrogen after six years of corn production. Soil Sci. 153, 307-313.

Löhnertz, O., 1991. Soil nitrogen and the uptake of nitrogen in grapevines. In: Rantz, J.M. (ed). Proc. Int. Symp. on Nitrogen in Grapes and Wine, 18-19 June 1991, Seattle, Washington, USA. pp. 1-11.

Müller, K., 1986. Einfluss der Bewirtschaftung, Wasserversorgung und Düngung von Weinbergsboden auf den Traubenertrag und die Mostqualität. Mitt. Klosterneuburg 36, 101-110.

Neyroud, J.A. \& Parisod, J.F., 1983. Availability of mineral nitrogen to grapevines in relation to various fertiliser rates and cultural techniques. Rev. Suisse Vitic. Arboric. Hortic. 15, 367-371.

Peacock, W.L., Christensen, L.P. \& Broadbent, F.E., 1989. Uptake, storage and utilisation of soil-applied nitrogen by Thompson Seedless as affected by time of application. Am. J. Enol. Vitic. 40, 16-20.

Peacock, W.L., Christensen, L.P. \& Hirschfelt, D.J., 1991. Influence of timing of nitrogen fertilisation application on grapevines in the San Joaquin Valley. Am. J. Enol. Vitic. 42, 322-326.

Perret, P., Koblet, W. \& Haab, M., 1989. Bodenpflegemassnahmen zur Steuerung des zeitlichen Stickstoffangebotes im Rebbau. Schweiz. Z. Obst-u Weinb. 125, 616-623: 652-657.

Saayman, D., 1981. Wingerdvoeding. In: Burger, J. \& Deist, J. (eds). Wingerdbou in Suid-Afrika. Nietvoorbij, Stellenbosch, South Africa. pp. 343-383.

Saayman, D., \& Kleynhans, P.H., 1978. The effect of soil type on wine quality. In: Proc. $2^{\text {nd }}$ Congr. S. Afr. Soc. Enol. Vitic., 3-4 October 1978, Cape Town, South Africa. pp. 105-119.

Smart, R.E., Dick, J.K., Gravett, I.M. \& Fisher, B.M., 1990. Canopy management to improve grape yield and quality-Principles and practices. S. Afr. J. Enol. Vitic. $11,3-17$.

Soil Classification Working Group, 1991. Soil classification - A taxonomic system for South Africa. Department of Agricultural Development: Memoirs on natural agricultural resources of South Africa No. 15, Department of Agricultural Development, Pretoria, South Africa

Spayd, S.E., Wample, R.L., Stevens, R.G., Evans, R.G. \& Kawakami, A.K., 1993. Nitrogen fertilisation of White Riesling in Washington: Effects on petiole nutrient concentration, yield, yield components and vegetative growth. Am. J. Enol. Vitic. $44,378-386$

The Non-Affiliated Soil Analysis Work Committee, 1990. Handbook of standard soil testing methods for advisory purposes. Soil Sci. Soc. South Africa, Pretoria, South Africa.

Treeby, M.T., Holzapfel, B.P. \& Walker, R.R., 1995. Optimizing nitrogen supply to grafted Shiraz. In: Stockley, C.S., Sas, A.N., Johnstone, R.S. \& Lee, T.H. (eds). Proc. $9^{\text {th }}$ Aust. Wine Ind. Tech. Conf., 16-19 July 1995, Adelaide, Australia. pp. 132-137.

Van Huyssteen, L. \& Conradie, W.J., 1990. Influence sur l'environment des techniques d'entretien et de fertilisation des sols viticoles, particulierement dans vignoble Sud-African. Proc. $70^{\text {th }}$ General Assembly of the Office International de la vigne et du vin (OIV), 3-13 September 1990, Yalta, USSR. pp. 1-16.

Van Zyl, J.L. \& Weber, H.W., 1981. The effect of various supplementary irrigation treatments on plant and soil moisture relationships in a vineyard (Vitis Vinifera var. Chenin blanc). S. Afr. J. Enol. Vitic. 2, 83-99.

Williams, L.E., 1991. Vine nitrogen requirements - utilisation of $\mathrm{N}$-sources from soils, fertilisers and reserves. In: Rantz, J.M. (ed). Proc. Int. Symp. on Nitrogen in Grapes and Wine, 18-19 June 1991, Seattle, Washington, USA. pp. 62-66.

Zeeman, A.S., 1981. Oplei. In: Burger, J. \& Deist, J. (eds). Wingerdbou in SuidAfrika. Nietvoorbij, Stellenbosch, South Africa. pp. 185-201.

Zeeman, A.S. \& Archer, E., 1981. Stokontwikkeling, wintersnoei en somerbehandeling. In: Burger, J. \& Deist, J. (eds). Wingerdbou in Suid-Afrika. Nietvoorbij, Stellenbosch, South Africa. pp. 202-233. 